Received 04.04.2014 Reviewed 18.05.2014 Accepted 02.06.2014

A - study design

B - data collection

C - statistical analysis

D - data interpretation

$\mathbf{E}$ - manuscript preparation

F - literature search

\section{Age and land use as factors differentiating hydrochemistry and plant cover of astatic ponds in post-agricultural landscape}

\author{
Monika MĘTRAK ${ }^{\text {ABCDEF }}$, Pawel PAWLIKOWSKI ${ }^{\text {BD }}$, \\ Malgorzata SUSKA-MALAWSKA ${ }^{\text {ABD }}$
}

University of Warsaw, Faculty of Biology, Biological and Chemical Research Centre, ul. Żwirki i Wigury 101, 02-089 Warsaw, Poland; tel. +48 225526 542, e-mail: mmetrak@biol.uw.edu.pl

For citation: Mętrak M., Pawlikowski P., Suska-Malawska M. 2014. Age and land use as factors differentiating hydrochemistry and plant cover of astatic ponds in post-agricultural landscape. Journal of Water and Land Development. No. 21 p. $29-37$

\begin{abstract}
Small, astatic ponds are important features of post-glacial landscape, which support heterogeneity and biodiversity of agricultural areas. In the presented research we explored differences in hydrochemistry and plant cover of 20 small ponds located in Northeastern Poland, characterized by diverse age and developed in differently managed areas. According to our research, though changes in water level are under direct influence of water balance in the catchment, to which belonged the ponds, their hydrochemistry seemed to be shaped by processes at the level lower than the catchment scale. Age of the ponds appeared to be an important factor influencing density and species composition of vegetation developed on the studied ponds.
\end{abstract}

Key words: astatic ponds, vegetation, water chemistry

\section{INTRODUCTION}

In Europe, small ponds are typical for young post-glacial landscape, and as such they are located in areas adapted mostly for agricultural purposes. Therefore, they are under constant threat of intensive agrarian practices, such as fertilizing or drainage. In order to increase the arable area, some ponds are filled and leveled, others are used as local dumping sites, which leads to their irreversible degradation. It is estimated that during the $20^{\text {th }}$ century even $40-90 \%$ of ponds had been lost in Northwestern Europe, despite their important role as ecotonal zones supporting biodiversity and heterogeneity of agricultural landscape - e.g. refuge for rare plant species, amphibian spawning areas, birds nesting and feeding sites [DECLERCK et al. 2006; GIORIA et al. 2010; KIRKMAN et al. 2012; KŁOSOWSKI, JABŁOŃSKA 2009; NICOLET et al. 2004; PATZIG et al. 2012; THIERE et al. 2009]. Moreover, small ponds are critical for catchment water balance (especially in closed catchments), local temperature and humidity regulation, and mitigation of environmental pollution [BOIX et al. 2012; DowNING et al. 2010; GIORIA et al. 2010; KIRKMAN et al. 2012; MIRACLE et al. 2010; 2006; NiCOLET et al. 2004; ZUBALA 2005].

As small-sized, shallow and often isolated water bodies, ponds are characterized by high variability of hydrogeomorphic conditions (astatic ponds), in some cases leading to distinct wet and dry cycles (temporary ponds). Due to dynamic character of astatic ponds, their water chemistry tends to be poorly predictable and its patterns remain unique for particular water bodies. Therefore, both plants and animals inhabiting astatic ponds are characterized by wide ecological amplitudes and phenotypic plasticity, that enable them to survive significant changes in water chemistry, as well as periods of drought [LUKACS et al. 2013; PATZIG et al. 2012; TABOSA et al. 2012; ZACHARIAS et al. 2007]. 
After each dry phase, small ponds are colonized anew and, hence, can be viewed as islands both in space and in time [ANGELER, ALVAREZ-COBELAS 2005; RICKFELS, LOVETTE 1999]. However, under favorable climatic conditions or after implementation of hydrologic improvements, small ponds may turn perennial. In such case, they will be subjected to succession processes, leading to withdrawal of the first-to-colonize eurytopic species and development of stable vegetation zones, resembling those in lakes, yet with higher proportion of reedswamp and pleustonic communities [KŁOSOWSKI, JABŁOŃSKA 2009].

In case of astatic ponds, there are three main factors influencing both plant and animal species distribution and diversity: (1) isolation, (2) hydroperiod and (3) age of a particular pond (e.g. KIRKMAN et al. [2012]; OLOMO et al. [2012]; RoLON et al. [2012]). In the man-made landscape, there are also anthropogenic factors that may affect biodiversity of astatic ponds [CAFFREY et al. 2006].

In the presented research we focus on three factors differentiating hydrochemistry and plant cover of astatic water bodies - age of a pond, its isolation and type of land use in its immediate surroundings. The last two factors are known for shaping species composition of pond vegetation (distance from and type of potential sources of species). Age of a pond affects dynamics of its hydrochemistry and advance of succession processes [e.g. KIRKMAN et al. 2012; OLOMO et al. 2012; RoLON et al. 2012]. Though hydroperiod is recognized as a factor influencing hydrochemistry and succession processes of ponds, we decided not to discuss it, because due to a narrow time frame of our research we could not propose any conclusive suppositions concerning hydroperiod of the studied water bodies.

\section{MATERIALS AND METHODS}

Research described in this article was conducted in post-glacial landscape of Northeastern Poland (the Masurian Lake District), where since the 1850s till 1990s intensive agricultural practices had been performed (Fig. 1).

After the collapse of state agricultural farms in the 1990s, described area was left fallow and included into the Masurian Landscape Park as semi-natural meadows subjected to extensive mowing. Agricultural practices were continued only in location of ponds from the group C. In 2009 water retention program have been implemented in the neighboring Puszcza Piska Forest, resulting in major hydrological changes on the fallows. These changes were reinforced due to intensive beaver activity. As a result, on previously drained areas numerous small water bodies have emerged lately, increasing heterogeneity of post-agricultural landscape.

For the purpose of our study we chose 20 astatic ponds of different age and divided them into the following groups:

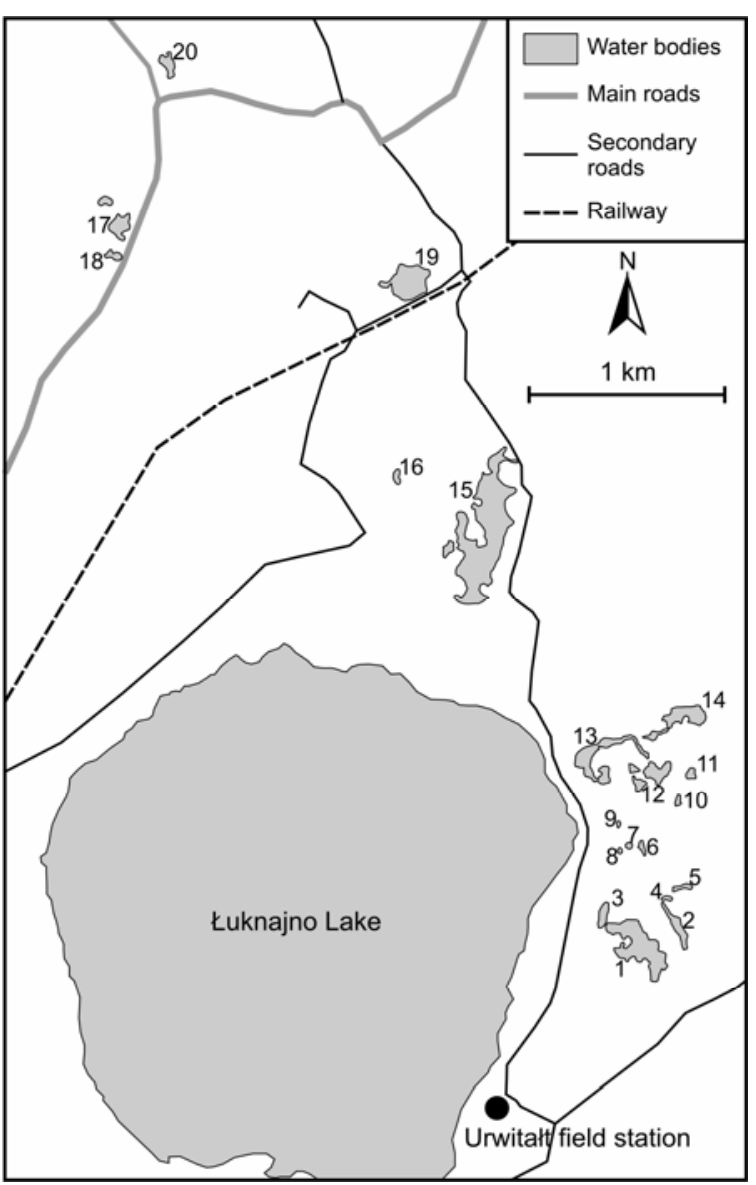

Fig. 1. Location of the studied ponds; source: own elaboration

1) group A (9 ponds) - young ponds (some of them established in 2007), densely spread on the fallows (semi-natural meadows);

2) group B (7 ponds) - old ponds (local inhabitants confirmed their existence in the 1980's), densely spread on the fallows (semi-natural meadows);

3) group C (4 ponds) - old ponds, separated from others by the road, surrounded by cultivated fields.

All the ponds were located near the Luknajno Lake. The lake and fen communities developed on its shores are a UNESCO Biosphere Reserve (since 1972) and are also protected by Ramsar Convention (since 1977) [JABŁOŃSKA-BARNA 2007]. Basic characteristics of the studied ponds are presented in the Table 1.

To assess plant biodiversity and succession, a phytosociological survey was performed according to the Braun-Blanquet method on the ponds and in their surroundings [MATUSZKIEWICZ 2001]. For the purpose of further studies, on every pond, in the areas covered with particular vegetation types, a set of monitoring points was established. Moreover, a network of piezometers was created, showing groundwater level in the immediate vicinity of each pond. During the growing season of 2010 and 2011 water samples were taken (April, July and September) from the monitoring points and groundwater level was measured in the piezometers. 
Table 1. Characteristics of the studied ponds

\begin{tabular}{|r|r|r|r|c|}
\hline Pond & Area, $\mathrm{m}^{2}$ & $\begin{array}{c}\text { Distance from } \\
\text { the Luknajno } \\
\text { Lake, } \mathrm{m}\end{array}$ & $\begin{array}{c}\text { Average } \\
\text { water depth } \\
\mathrm{cm}\end{array}$ & $\begin{array}{c}\text { Annual water } \\
\text { level } \\
\text { dynamics }\end{array}$ \\
\hline 1 & 39900 & 400 & 64 & 1 \\
\hline 2 & 6040 & 500 & 79 & 1 \\
\hline 3 & 8200 & 320 & 38 & 1 \\
\hline 4 & 860 & 500 & 38 & 1 \\
\hline 5 & 2000 & 570 & 5 & 2 \\
\hline 6 & 1730 & 320 & 28 & 1 \\
\hline 7 & 1000 & 270 & 16 & 2 \\
\hline 8 & 700 & 220 & 10 & 2 \\
\hline 9 & 600 & 210 & 5 & 2 \\
\hline 10 & 1500 & 500 & 1 & 3 \\
\hline 11 & 3700 & 590 & 20 & 1 \\
\hline 12 & 15000 & 430 & 28 & 1 \\
\hline 13 & 18000 & 150 & 29 & 2 \\
\hline 14 & 16000 & 520 & 2 & 3 \\
\hline 15 & 91900 & 480 & 64 & 1 \\
\hline 16 & 2500 & 919 & 14 & 2 \\
\hline 17 & 10130 & 2200 & 81 & 1 \\
\hline 18 & 3500 & 2090 & 12 & 3 \\
\hline 19 & 29550 & 1850 & 110 & 1 \\
\hline 20 & 5196 & 3100 & 90 & 1 \\
\hline
\end{tabular}

Note: annual dynamics of water level is shown according to the 1-3 scale: (1) no significant water level changes during the year; (2) significant drop of water level in summer; (3) complete drying out of the pond in summer or freezing in winter. Areas and distances given in the table were determined according to GPS measurements

Source: own study.

Laboratory analyses: Most analyses were performed on fresh water samples immediately after arrival. Analyses of phosphates, total iron, nitrates and ammonia ions were conducted on samples preserved with $1 \% \mathrm{HCl}$ and stored in dark, cool place. The following analyses were performed according to the Polish Norms for water chemistry: $\mathrm{pH}$ (using $\mathrm{pH}$-meter), electrolytic conductivity (EC, using conductometer), carbonate hardness $(\mathrm{CH}$, Warthy-Pfeifer method), content of sodium, potassium, calcium and magnesium ions $\left(\mathrm{Na}^{+}, \mathrm{K}^{+}, \mathrm{Ca}^{2+}, \mathrm{Mg}^{2+}\right.$ extracted with ammonium acetate and measured with flame atomic absorption spectrometer), total iron content ( $\mathrm{Fe}_{\text {tot }}$, rhodanate method), chloride ions (titration method), sulfate ions $\left(\mathrm{SO}_{4}{ }^{2-}\right.$, nephelometric method), phosphate ions $\left(\mathrm{PO}_{4}{ }^{3-}\right.$ , molybdate method), ammonium and nitrate ions $\left(\mathrm{NH}_{4}^{+}\right.$and $\mathrm{NO}_{3}{ }^{-}$, spectrophotometrically).

All analyses were performed in the Laboratory of Environmental Chemistry in the University of Warsaw Biological and Chemical Research Centre (UW CBRC).

Statistical analyses: For the assessment of differences in hydrochemistry and vegetation cover among ponds of different age the following analyses were performed:

1) Kruskal-Wallis one-way analysis of variance for estimation of differences in water level and hydrochemistry;

2) Friedman's ANOVA for estimation of differences in water level and hydrochemistry among the con- secutive sampling times (samples from the same monitoring point treated as dependent);

3) PCA (Primary Component Analysis) for estimation of variance among relevés from the different groups of ponds;

4) RDA (Redundancy Analysis) for estimation of variance in vegetation cover explained by the implemented division into groups of ponds;

5) Shannon-Weaver index $H$ for estimation of plant biodiversity on the studied ponds and Kruskal Wallis one-way analysis of variance for assessment of differences in biodiversity between groups of ponds;

6) Spearman's rank correlation coefficients for estimation of relation between biodiversity indices and surface area of ponds.

Statistical analyses were performed with the use of CANOCO for Windows Version 4.5 [SIMLAUER, 2014] and Statistica 10.

\section{RESULTS}

\section{GENERAL CHARACTERISTICS AND HYDROCHEMISTRY OF THE STUDIED PONDS}

The studied ponds were mostly small and shallow water bodies (an average surface area below 1 ha and an average depth below $1 \mathrm{~m}$ ), formed in post-glacial peat-filled hollows with no outflow of surface waters. They all showed the same pattern of seasonal water level changes, as measured with piezometers in an immediate proximity of the ponds (Fig. 2).

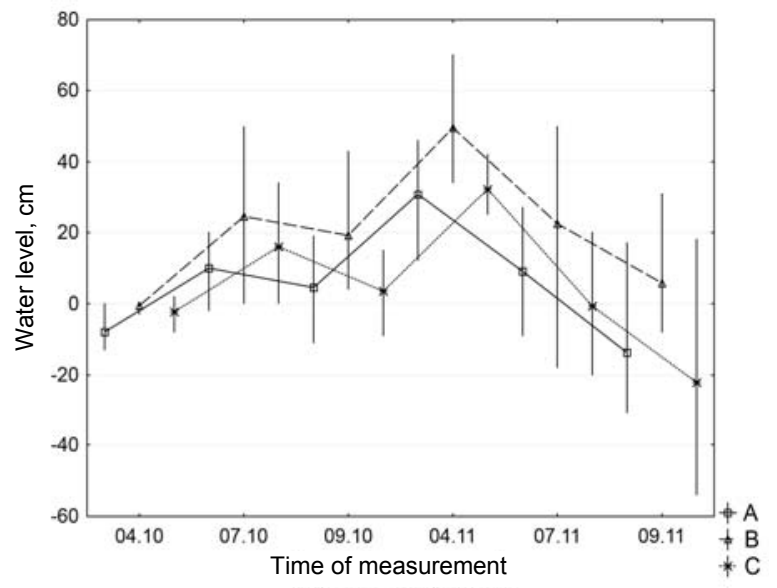

Fig. 2. Seasonal changes in the water level for the ponds from the groups A (young ponds on the fallows), B (old ponds on the fallows) and $\mathrm{C}$ (old ponds in the cultivated

fields); source: own study

Further statistical analyses (i.e. Spearman's rank correlation, regression) performed separately for each group of ponds, showed that though we could observe seasonal fluctuations of some of the studied chemical parameters, they were not correlated to the changes in water level. 
The young ponds from the group A were the most alkaline ones, with an average $\mathrm{pH}$ of 7.15 . They were also the richest in calcium ions (on average 41.31 $\left.\mathrm{mg} \cdot \mathrm{dm}^{-3}\right)$. Theses two features differentiating the young ponds form the old ponds were statistically important with $\mathrm{p}$ value of 0.0062 in case of $\mathrm{pH}$ and 0.0274 in case of calcium concentration. Young ponds were also characterized by the highest electrolytic conductivity and carbonate hardness, the highest concentration of potassium ions, nitrates and phosphates, yet these observations had no statistical importance.
Discriminating feature for the old ponds from the groups $\mathrm{B}$ and $\mathrm{C}$ was the water level, which was significantly higher than in the young ponds ( $p=$ 0.0350). The highest water level was observed for the ponds from the group B, with the biannual average of $16 \mathrm{~cm}$. We also recorded higher concentrations of sodium, magnesium and iron ions, as well as ammonium ions, chlorides and sulphates in the water from the old ponds, yet these differences were not of statistical importance. Detailed characteristics of hydrochemistry of ponds belonging to the distinguished groups is shown in Table 2.

Table 2. Chemical characteristics of the ponds from the groups A (young ponds on the fallows), B (old ponds on the fallows) and $\mathrm{C}$ (old ponds in the cultivated fields)

\begin{tabular}{|c|c|c|c|c|c|}
\hline Parameter & & $\begin{array}{c}\text { Group A } \\
\mathrm{N}=60\left(\mathrm{~N}_{\mathrm{Mg}}=36\right)\end{array}$ & $\begin{array}{c}\text { Group B } \\
\mathrm{N}=47\left(\mathrm{~N}_{\mathrm{Mg}}=26\right)\end{array}$ & $\begin{array}{c}\text { Group C } \\
\mathrm{N}=27\left(\mathrm{~N}_{\mathrm{Mg}}=12\right)\end{array}$ & $\begin{array}{c}\text { Statistics } \\
\text { (Kruskal-Wallis test) }\end{array}$ \\
\hline $\begin{array}{l}\text { Water level } \\
\mathrm{cm}\end{array}$ & $\begin{array}{l}\text { mean } \\
\text { median } \\
\text { range }\end{array}$ & $\begin{array}{c}6(S D=16) \\
7^{\mathrm{B}} \\
(-31)-46\end{array}$ & $\begin{array}{c}16(S D=23) \\
15^{\mathrm{A}} \\
(-54)-70\end{array}$ & $\begin{array}{c}8(S D=19) \\
7.5 \\
(-43)-42\end{array}$ & $\begin{array}{c}H=6.71 \\
p=0.0350\end{array}$ \\
\hline $\begin{array}{c}\mathrm{Na} \\
\mathrm{mg} \cdot \mathrm{dm}^{-3}\end{array}$ & $\begin{array}{l}\text { mean } \\
\text { median } \\
\text { range }\end{array}$ & $\begin{array}{c}1.28(S D=1.14) \\
0.58 \\
0.11-3.81\end{array}$ & $\begin{array}{c}1.18(S D=1.03) \\
0.74 \\
0.10-3.34\end{array}$ & $\begin{array}{c}1.74(S D=2.10) \\
1.17 \\
0.13-8.48\end{array}$ & $\begin{array}{c}H=1.02 \\
p=0.5991\end{array}$ \\
\hline$\underset{\mathrm{mg} \cdot \mathrm{dm}^{-3}}{\mathrm{~K}}$ & $\begin{array}{l}\text { mean } \\
\text { median } \\
\text { range }\end{array}$ & $\begin{array}{c}4.39(S D=5.03) \\
2.96 \\
0.21-31.40\end{array}$ & $\begin{array}{c}3.76(S D=4.10) \\
2.21 \\
0.27-23.00\end{array}$ & $\begin{array}{c}3.35(S D=3.17) \\
2.24 \\
0.33-11.97\end{array}$ & $\begin{array}{c}H=1.03 \\
p=0.5960\end{array}$ \\
\hline $\begin{array}{c}\mathrm{Ca} \\
\mathrm{mg} \cdot \mathrm{dm}^{-3}\end{array}$ & $\begin{array}{l}\text { mean } \\
\text { median } \\
\text { range } \\
\end{array}$ & $\begin{array}{c}41.31(S D=15.10) \\
43.25^{\mathrm{B}} \\
1.10-77.40\end{array}$ & $\begin{array}{c}36.61(S D=18.06) \\
35.60^{\mathrm{A}} \\
2.40-79.30\end{array}$ & $\begin{array}{c}32.60(S D=16.92) \\
30.30 \\
4.50-64.30\end{array}$ & $\begin{array}{c}H=7.20 \\
p=0.0274\end{array}$ \\
\hline $\begin{array}{c}\mathrm{Mg} \\
\mathrm{mg} \cdot \mathrm{dm}^{-3}\end{array}$ & $\begin{array}{l}\text { mean } \\
\text { median } \\
\text { range } \\
\end{array}$ & $\begin{array}{c}6.83(S D=2.88) \\
7.10 \\
1.16-13.64 \\
\end{array}$ & $\begin{array}{c}7.80(S D=3.16) \\
7.54 \\
3.13-13.68\end{array}$ & $\begin{array}{c}6.35(S D=3.58) \\
5.46 \\
3.10-13.34 \\
\end{array}$ & $\begin{array}{c}H=2.86 \\
p=0.2390\end{array}$ \\
\hline $\begin{array}{c}\mathrm{Fe} \\
\mathrm{mg} \cdot \mathrm{dm}^{-3}\end{array}$ & $\begin{array}{l}\text { mean } \\
\text { median } \\
\text { range }\end{array}$ & $\begin{array}{c}2.07(S D=3.24) \\
0.96 \\
0.11-19.29\end{array}$ & $\begin{array}{c}2.14(S D=4.88) \\
0.99 \\
0.13-33.22\end{array}$ & $\begin{array}{c}1.02(S D=1.11) \\
0.58 \\
0.03-4.63\end{array}$ & $\begin{array}{c}H=2.53 \\
p=0.2825\end{array}$ \\
\hline $\begin{array}{c}\mathrm{EC} \\
\mathrm{mS} \cdot \mathrm{cm}^{-1}\end{array}$ & $\begin{array}{l}\text { mean } \\
\text { median } \\
\text { range }\end{array}$ & $\begin{array}{c}320(S D=325) \\
325 \\
54-632\end{array}$ & $\begin{array}{c}319(S D=219) \\
262 \\
78-1425\end{array}$ & $\begin{array}{c}280(S D=144) \\
253 \\
65-558\end{array}$ & $\begin{array}{c}H=2.08 \\
p=0.3528\end{array}$ \\
\hline $\mathrm{pH}$ & $\begin{array}{l}\text { mean } \\
\text { median } \\
\text { range }\end{array}$ & $\begin{array}{c}7.15(S D=0.52) \\
7.21^{\mathrm{B}} \\
6.03-8.56\end{array}$ & $\begin{array}{c}6.87(S D=0.39) \\
6.91^{\mathrm{A}} \\
5.84-7.48\end{array}$ & $\begin{array}{c}7.02(S D=0.49) \\
7.03 \\
5.94-8.28\end{array}$ & $\begin{array}{l}H=10.16 \\
p=0.0062\end{array}$ \\
\hline $\begin{array}{c}\mathrm{CH} \\
\text { hardness } \\
\text { degree }\end{array}$ & $\begin{array}{l}\text { mean } \\
\text { median } \\
\text { range }\end{array}$ & $\begin{array}{c}13.27(S D=5.21) \\
12.65 \\
3.25-27.22\end{array}$ & $\begin{array}{c}12.52(S D=5.68) \\
11.42 \\
5.35-33.40\end{array}$ & $\begin{array}{c}11.79(S D=5.26) \\
9.83 \\
4.42-19.88\end{array}$ & $\begin{array}{c}H=2.04 \\
p=0.3601\end{array}$ \\
\hline $\begin{array}{c}\mathrm{Cl} \\
\mathrm{mg} \cdot \mathrm{dm}^{-3}\end{array}$ & $\begin{array}{l}\text { mean } \\
\text { median } \\
\text { range }\end{array}$ & $\begin{array}{c}10.55(S D=7.06) \\
11.27 \\
1.50-37.50\end{array}$ & $\begin{array}{c}9.88(S D=6.61) \\
11.80 \\
1.25-28.00\end{array}$ & $\begin{array}{c}12.76(S D=11.06) \\
9.50 \\
1.50-44.20\end{array}$ & $\begin{array}{c}H=0.52 \\
p=0.7706\end{array}$ \\
\hline $\begin{array}{l}\mathrm{N}-\mathrm{NH}_{4} \\
\mathrm{mg} \cdot \mathrm{dm}^{-3}\end{array}$ & $\begin{array}{l}\text { mean } \\
\text { median } \\
\text { range }\end{array}$ & $\begin{array}{c}1.32(S D=1.25) \\
0.90 \\
0.03-6.38\end{array}$ & $\begin{array}{c}1.38(S D=1.02) \\
1.23 \\
0.07-4.01\end{array}$ & $\begin{array}{c}1.17(S D=0.83) \\
1.02 \\
0.15-3.94\end{array}$ & $\begin{array}{c}H=0.93 \\
p=0.6286\end{array}$ \\
\hline $\begin{array}{l}\mathrm{N}-\mathrm{NO}_{3} \\
\mathrm{mg} \cdot \mathrm{dm}^{-3}\end{array}$ & $\begin{array}{l}\text { mean } \\
\text { median } \\
\text { range }\end{array}$ & $\begin{array}{c}0.23(S D=0.22) \\
0.21 \\
0.03-1.67\end{array}$ & $\begin{array}{c}0.28(S D=0.78) \\
0.17 \\
0.07-2.99\end{array}$ & $\begin{array}{c}0.55(S D=0.98) \\
0.30 \\
0.02-5.23\end{array}$ & $\begin{array}{c}H=1.85 \\
p=0.6920\end{array}$ \\
\hline $\begin{array}{c}\mathrm{P}-\mathrm{PO}_{4} \\
\mathrm{mg} \cdot \mathrm{dm}^{-3}\end{array}$ & $\begin{array}{l}\text { mean } \\
\text { median } \\
\text { range }\end{array}$ & $\begin{array}{c}0.86(S D=1.18) \\
0.41 \\
0.06-5.37\end{array}$ & $\begin{array}{c}0.64(S D=0.82) \\
0.37 \\
0.065-3.52\end{array}$ & $\begin{array}{c}0.50(S D=0.89) \\
0.27 \\
0.02-5.23\end{array}$ & $\begin{array}{c}H=3.48 \\
p=0.3965\end{array}$ \\
\hline $\begin{array}{c}\mathrm{S}_{-} \mathrm{SO}_{4} \\
\mathrm{mg} \cdot \mathrm{dm}^{-3}\end{array}$ & $\begin{array}{l}\text { mean } \\
\text { median } \\
\text { range }\end{array}$ & $\begin{array}{c}3.00(S D=1.56) \\
2.53 \\
0.86-7.70\end{array}$ & $\begin{array}{c}3.64(S D=2.54) \\
2.64 \\
1.34-14.40\end{array}$ & $\begin{array}{c}3.50(S D=2.17) \\
3.11 \\
0.57-8.87\end{array}$ & $\begin{array}{c}H=1.33 \\
p=0.5144\end{array}$ \\
\hline
\end{tabular}

Explanation: letters in superscripts denote between which groups statistically important differences were observed. Source: own study. 
We found no particular, statistically important chemical characteristics, that could discriminate the old ponds surrounded by cultivated fields from the old ponds located on the fallows.

\section{VEGETATION COVER OF THE STUDIED PONDS}

In case of the young ponds from the group A, high percentage of their surface was covered with aquatic vegetation, typical for the open water (Fig. 3).

Moreover, very often more than $50 \%$ of the ponds' surface was covered with one uniform type of vegetation e.g. on the ponds 4,5 and 8 - reedbeds, on the pond 3 - aquatic vegetation, on the pond 7 - shrubs typical for alder forests and on the pond 9 sparse vegetation of periodically flooded areas.

Participation of aquatic vegetation in the surface cover of the old ponds from the groups $\mathrm{B}$ and $\mathrm{C}$ was generally lower than for the young ponds. On the ponds from the group B dominance of one vegetation type was not so clearly visible. Usually the ponds' surface was covered with 2-3 main types of vegetation. Reedbeds and shrubs were more common there than on the ponds from the groups $\mathrm{A}$ and $\mathrm{C}$. The ponds from the group $\mathrm{C}$ were characterized by strong dominance of Typha latifolia reedbeds, covering more than $50 \%$ of their surface.

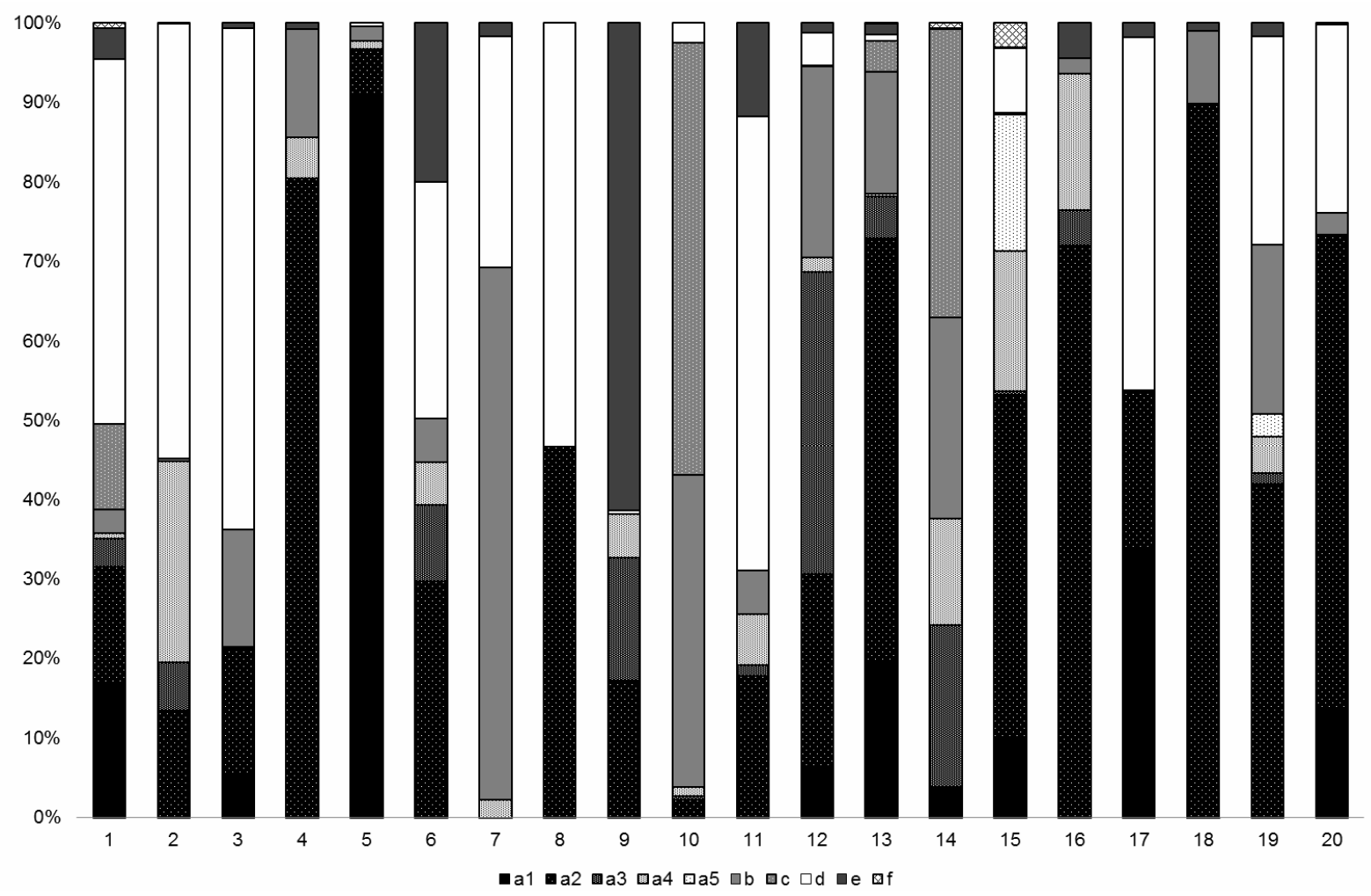

Fig. 3. Percentage cover of pond surface by distinguished ecological vegetation types; a1 - Phragmites australis reedbeds; a2 - Typha latifoliae reedbeds; a3 - reedbeds from the Magnocaricion alliance; a4 - Phalaris arundinacea reedbeds; a5 - Equisetum limosum reeddbeds; b - willow shrublands; c - swampy alder forests; $\mathrm{d}$ - aquatic vegetation; $\mathrm{e}$ - sparse vegetation of shallow waters and periodically flooded areas; $\mathrm{f}$ - vegetation of moist, mineral soils; source: own study

According to the PCA presented on Figure 4, relevés made on the young ponds from the group A and the old ponds from the group $\mathrm{C}$ formed two rather dense, distinguishable assemblages, while relevés made on the old ponds from the group B were widely dispersed on the diagram, showing different degree of resemblance to relevés from the groups $\mathrm{A}$ and $\mathrm{C}$.

The RDA (Fig. 5) showed, that the implemented division of ponds into three groups explained $17 \%$ of the observed variance in the species composition on these water bodies.

For the young ponds from the group A typical open water species were characteristic (Lemna turinifera, Lemna trisulca). On the old ponds located on the semi-natural meadows (group B) species typical for wet meadows and tall-sedge reedbeds were the most common i.a. Cirsium palustre and Scirpus sylvaticus from Molinietalia caeruleae W. Koch 1926 order and several species of Carex sp. from Magnocaricion Koch 1926 alliance. Ponds from the group B were also characterized by occurrence of typical hydrophytes, such as Eleocharis palustris, Hottonia palustris and Utricularia vulgaris, though with the exception of the pond no. 11, they cover rather small parts of the ponds' surface. In case of the old ponds located on cultivated fields (group C), they were covered mostly with Typha latifolia reedbeds (Phragmition Koch 1926 alliance), yet we observed there many species typical for semi-natural and anthropogenic meadows and ruderal communities, even weeds i.a. 


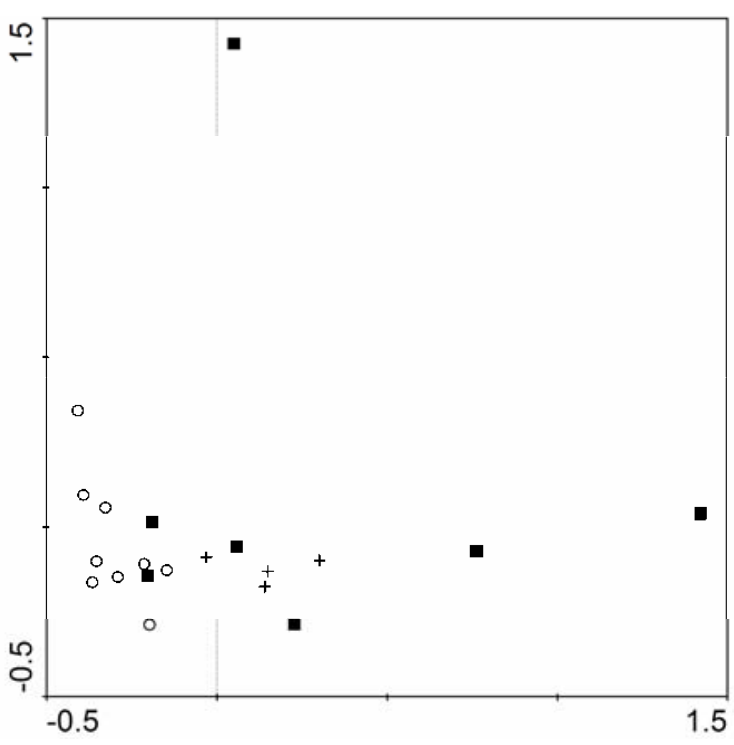

Fig. 4. PCA of relevés from the different ponds (eigenvalues of the first two axes: $\left.\lambda_{1}=0.188 ; \lambda_{2}=0.125\right)$; circles - ponds from the group A (young ponds on the fallows); squares ponds from the group B (old ponds on the fallows); crosses - ponds from the group $\mathrm{C}$ (old ponds in the cultivated fields); source: own study

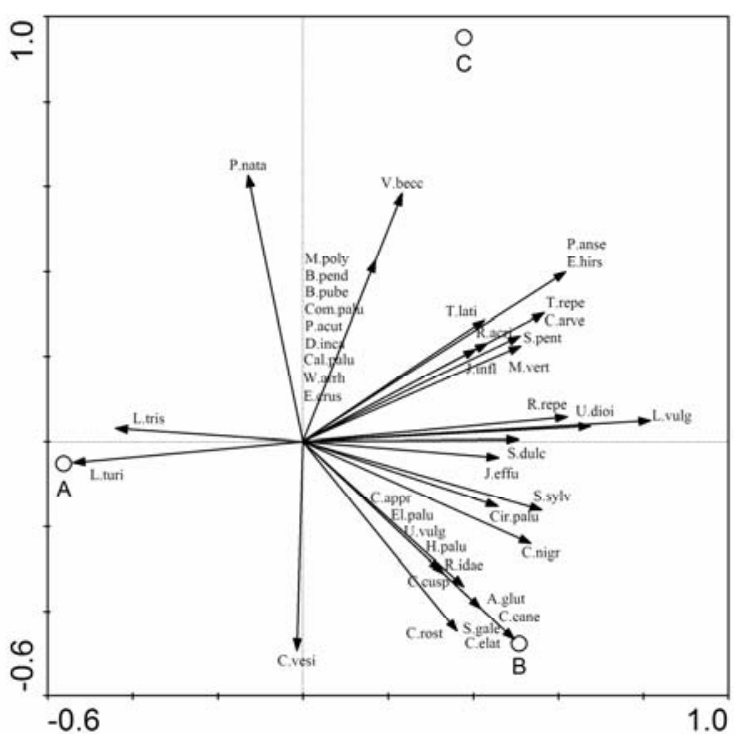

Fig. 5. RDA of relevés from the different ponds with implemented division into groups as an independent variable (eigenvalues of the first two axes: $\lambda_{1}=0.105$; $\lambda_{2}=0.066 ; p=0.002$ ); for the species shown on the diagram, division into groups explains at least $17 \%$ of variance in species abundance; source: own study

Potentilla anserina and Trifolium repens from Molinio-Arrhenatheretea R.Tx. 1937 class, Urtica dioica and Epilobium hirsutum from Artemisietea vulgaris Lohm., Prsg et R.Tx. in R.Tx. 1950 class and Echinochloa crus-galli from Polygono-Chenopodietalia (R.Tx. et Lohm. 1950) J.Tx. 1961 class.

Summarizing, the young ponds were characterized by the lowest species richness $R$ and Shannon-Weaver index $H$ - on average $R=28$, range 16-39, average $H=1.35$. For the old ponds located on culti- vated fields species richness amounted on average to 39 species per pond, ranging from 24 to 45 and on average $H=1.51$. The highest values of biodiversity indices were recorded for the old ponds located on semi-natural meadows - on average 46 species per pond, ranging from 29 to 61 , on average $H=1.59$. Observed differences were statistically important with $p$ values of 0.0174 for species richness $R$ and 0.0136 for Shannon-Weaver index $H$. Both species richness and Shannon-Weaver index showed strong positive correlation to surface area of ponds $-r_{R}=0.75, p=$ $0.0001, C I_{95 \%}\{0.46,0.89\}$ and $r_{H}=0.74, p=0.0001$, $C I_{95 \%}\{0.44,0.89\}$.

\section{DISCUSSION}

\section{GENERAL CHARACTERISTICS AND HYDROCHEMISTRY OF THE STUDIED PONDS}

Observed pattern of seasonal water level changes was the same for the ponds from all the distinguished groups, showing its dependence on processes on the catchment scale, rather than on local level. During the second year of studies water level changes were typical for the ponds located in central Europe. The highest water level was observed in spring, when temperatures rise above zero and snow starts to melt, providing influx of surface waters. During summer and autumn exceeding evaporation rates and decrease in precipitation, cause gradual lessening of ponds surface and depth (with high ratio of surface to depth maintained during whole wet phase). However, during the first year of research, seasonal water level fluctuations in the ponds didn't follow this rule. The spring of 2010 was characterized by the lowest water levels, which during the following months raised steadily and remained on the same level till September. These irregularity was probably an effect of meteorological conditions in winter and spring of the year 2010. According to the data provided by the Institute of Meteorology and Water Management, in the year 2010 the amount of snow fallen altogether in January and February was relatively low (48 $\mathrm{mm}$ in 2010 comparing to $72 \mathrm{~mm}$ in 2011), which may have caused differences in the surface water run-off in spring. Moreover, April of 2010 was much drier comparing to April of 2011 (30 mm of precipitation in 2010 and $45 \mathrm{~mm}$ in 2011).

Temporary ponds are highly fluctuant environments, whose water chemistry is variable and can be rapidly changed by influxes of organic and inorganic substances from the catchment area [KUCZYŃSKAKIPPEN 2009; MIRACLE et al. 2010]. In our case, though some water parameters showed seasonal fluctuations, they were not related to the changes in water level, which underlines the importance of local differences and processes, operating at the level lower than the catchment scale.

As far as differences in chemistry among the groups of ponds are concerned, the old ponds from 
the group B were characterized by significantly lower $\mathrm{pH}$ and lower concentration of calcium ions than ponds from the young ponds from the group A. These observations are in good agreement with OLMO et al. [2012], who stated that recently restored ponds had the highest conductivity, oxygen and $\mathrm{pH}$, whilst the old ponds were those with the lowest levels. Such changes of water chemistry in the different-aged ponds result from plant succession. Following restoration of a pond, helophytes start to grow, that will enrich the sediment in organic matter, thus gradually decreasing oxygen and altering $\mathrm{pH}$. Simultaneously, rain washes ions from the pond's sediments, causing slight decrease in conductivity [OLMO et al. 2012]. In our case, such decrease in conductivity was not visible. Probably, because OLMO et al. [2012] studied ponds established on sandy sediments, and our ponds were underlain by peat sediments, which thanks to their high sorption capacity could act as a source of ions in water.

\section{VEGETATION COVER OF THE STUDIED PONDS}

Plant species observed on the studied astatic ponds were usually characterized by wide ecological amplitude and phenotypic plasticity, considering water level and chemistry. These features enabled them to survive in highly labile conditions of astatic ponds. In our case, emergent plants comprised $86 \%$ of all recorded species, with $8 \%$ constituted by submerged plants and $6 \%$ by floating-leaved plants. Typically, emergent plant species are much more commonly observed on astatic ponds than fully aquatic species, and hence constitute majority of recorded species richness [NICOLET et al. 2004; TABOSA et al. 2012]. These amphibious and often generalist species function usually as metapopulations in an environmental matrix surrounding neighboring ponds, which is for them sufficiently permeable [ROLON et al. 2012].

However, considering percentage cover of the ponds' surface, hydrophytes (both submerged and floating-leaved) covered on average $30 \%$ of the young ponds, $23 \%$ of the old ponds located on cultivated fields and only $10 \%$ of the old ponds in semi-natural surroundings. The young ponds were also characterized by the presence of muddy patches with sparse vegetation, which covered on average $10 \%$ of the ponds from the group A. For the old ponds from the groups $\mathrm{B}$ and $\mathrm{C}$ muddy patches covered on average less than $3 \%$ of the ponds. Presented features of plant cover, together with the lowest biodiversity indices recorded for the young ponds, are characteristic for the early stages of plant succession of ponds. Species richness and densities of plants and animals inhabiting astatic ponds, increase over time, because of the longer exposure to immigrant arrival, which may result in additional opportunities for a more diverse array of organisms [OLMO et al. 2012]. Succession processes on astatic ponds will finally lead to development of stable vegetation zones [GIORIA et al. 2010; KIRKMAN et al. 2012; KŁOSOWSKI, JABŁOŃSKA 2009; THIERE et al. 2009]. In case of the studied ponds, stable zones will include different types of reed bed communities, as on the old ponds from the groups $\mathrm{B}$ and $\mathrm{C}$.

According to our PCA results, ponds from the groups $\mathrm{A}$ and $\mathrm{C}$ were characterized by distinct species composition. Ponds from these groups differed in age (young vs. old) and location (semi-natural meadows vs. cultivated fields). Moreover, they were separated by the longest distance, as the ponds from the group $\mathrm{C}$ were located northernmost and separated from others by the road. The young ponds from the group A were characterized by the high participation of typical hydrophytes in their vegetation cover. In case of the old ponds from the group $\mathrm{C}$, species characteristic for transformed ruderal sites were quite common, confirming agricultural practices in this area. Two out of seven relevés made on the ponds from the group B showed great similarity to species composition recorded on the ponds behind the road (group C). Two other relevés from the group B were similar to relevés made on the young ponds (group A). These observations suggest that plant communities on the ponds from the group B were formed with participation of species characteristic for the ponds from the groups A and $\mathrm{C}$. Yet, they were also supplied with species unique for this group. Among these species were plants typical for wet meadows and tall reedbeds, coming from the semi-natural meadows surrounding ponds from the group B. Due to the age of the ponds from the group B, meadow plants could form an important component of the vegetation cover.

Biodiversity indices of the studied ponds showed strong positive correlation to their surface areas, which corresponds with the island theory suggesting that the pond size may also influence the immigration and extirpation of species. It is commonly thought that "the bigger the pond, the better", because larger ponds receive more external propagules than smaller [ANGEler, Alvarez-COBElAS 2005; KIRKMAN et al. 2012; OERTLI et al. 2002]. Yet, it is also known, that small ponds surrounded by many potential sources of species (i.e. other ponds, wetlands, lakes) tend to receive even greater numbers of external plant propagules than larger but isolated ponds. These propagules not only contribute to recruitment of additional plant species, but also reduce extirpation rates of existing populations [ANGELER, ALVAREZ-COBELAS 2005; Chase, BEngtSSON 2010; KIRKMAN et al. 2012].

\section{CONCLUSIONS}

Water level fluctuations observed in the astatic ponds and their surroundings depended on the water balance in the catchment, which in turn was under direct influence of meteorological factors. Yet, local differences and processes at the level lower than the catchment scale seemed to be relevant for the dynamics of water chemistry in the ponds. Considering vegetation cover, age of the pond seemed to be an 
important factor affecting its density and composition. Young ponds were characterized by higher proportion of hydrophytes and sparse vegetation of periodically flooded areas in comparison to older water bodies. Biodiversity of the ponds' vegetation grew with the age and the surface of the studied water bodies.

\section{Acknowledgements}

This research was a part of a scientific project realized in the years 2009-2012 and financed by the funds from the National Science Centre of Poland, granted according to the decision number N N305 034637.

We wish to thank Monika Chmielewska, Iwona Ładziak and Katarzyna Sidoruk from the Laboratory of Environmental Chemistry of the University of Warsaw Biological and Chemical Research Centre (UW CBRC) for the performance of water analyses and the Institute of Meteorology and Water Management for the access to meteorological data.

\section{REFERENCES}

ANGELER D.G., Alvarez-CoBelas M. 2005. Island biogeography and landscape structure: Integrating ecological concepts in a landscape perspective of anthropogenic impacts in temporary wetlands. Environment Pollution. Vol. 138 p. 420-424.

Boix D., Biggs J., Cereghino R., Hull A.P., KalettKa T., Oertli B. 2012. Pond research and management in Europe: "Small is Beautiful". Hydrobiologia. Vol. 689. Iss. 1 p. 1-9.

Caffrey J.M., Monahan C., Tierney D. 2006. Factors influencing the distribution of aquatic plant communities in Irish canals. Hydrobiologia. Vol. 570 p. 133-139.

ChASE J.M., BenGTSSON J. 2010. Increasing spatio-temporal scales: metacommunity ecology. In: Community ecology: processes, models and applications. Ed. H.A. Verhoef, P.J. Morin. Oxford. Oxford University Press p. $57-68$.

Declerck S., De Bie T., ERcken D., Hampel H., SchriJVers S., Van Wichelen J., Gillard V., Mandiki R., Losson B., Bauwens D., KeiJers S., Vyverman W., Goddeeris B., De Meester L., Brendonck L., MarTENS K. 2006. Ecological characteristics of small farmland ponds: Associations with land use practices at multiple spatial scales. Biological Conservation. Vol. 131 p. 523-532.

DownING J.A. 2010. Emerging global role of small lakes and ponds: little things mean a lot. Limnetica. Vol. 29. No. 1 p. 9-24.

Downing J.A., Prairie Y.T., Cole J.J., Duarte C.M., TranviK L.J., Striegl R.G., Mcdowell W.H., KroteLAINEN P., CARACO N.F., MElack J.M., MidDElbURG J.J. 2006. The global abundance and size distribution of lakes, ponds, and impoundments. Limnology and Oceanography. Vol. 51. No. 5 p. 2388-2397.

Gioria M., Schaffer A., Bacaro G., Feehan J. 2010. The conservation value of farmland ponds: Predicting water beetle assemblages using vascular plants as surrogate group. Biological Conservation. R. 143 p. 1125-1133.

JABŁOŃSKA-BARNA I. 2007. Macroinvertebrate benthic communities in the macrophyte-dominated Lake Łuknajno (northeastern Poland). Oceanological and Hydrobiological Studies. International Journal of Oceanography and Hydrobiology. Vol. 34. Supl. 4 p. 29-37.
KiRKMAN L.K., SMith L.L., QUinTANA-AsCENCIO P.F., KaESER M.J., GOlladAy S.W., FARMER A.L. 2012. Is species richness congruent among taxa? Surrogacy, complementarity and environmental correlates among three disparate taxa in geographically isolated wetlands. Ecological Indicators. Vol. 18 p. 131-139.

KŁosOwSKI S., JABŁoŃSKA E. 2009. Aquatic and swamp plant communities as indicators of habitat properties of astatic water bodies in north-eastern Poland. Limnologica. Vol. 39. Iss. 2 p. 115-127.

KUCZYŃSKA-KIPPEN N. 2009. The spatial segregation of zooplankton communities with reference to land use and macrophytes in shallow Lake Wielkowiejskie (Poland). Internationale Revue der gesamten Hydrobiologie und Hydrographie. Vol. 94. Iss. 3 p. 267-281.

LuKaCs B.A., SRAmKo G., Molnar A. 2013. Plant diversity and conservation value of continental temporary pools. Biological Conservation. Vol. 158 p. 393-400.

MatUSZKIEWICZ W. 2001. Przewodnik do oznaczania zbiorowisk roślinnych Polski [Guide to plant communities in Poland]. Warszawa. Wydaw. Nauk. PWN. ISBN 8301135204 pp. 536.

Miracle M.R., Oertli B., Cereghino R., Hull A. 2010. Preface: conservation of european ponds - current knowledge and future needs. Limnetica. Vol. 29 p. 1-8.

Nicolet P., Biggs J., Fox G., Hodson M.J., Reynolds C., Whitfield M., Williams P. 2004. The wetland plant and macroinvertebrate assemblages of temporary ponds in England and Wales. Biological Conservation. Vol. 120 p. $261-278$.

Oertli B., Auderset Joye D., Castella E., Juge R., CamBIN D., Lachavanne J.B. 2002. Does size matter? The relationship between pond area and biodiversity. Biological Conservation. Vol. 104 p. 59-70.

Olmo C., Armengol X., Ortells R. 2012. Re-establishment of zooplankton communities in temporary ponds after autumn flooding: Does restoration age matter? Limnologica. Vol. 42 p. 310-319.

Patzig M., Kalettka T., Glemnitz M., Berger G. 2012. What governs macrophyte species richness in kettle hole types? A case study from Northeast Germany. Limnologica. Vol. 42 p. 340-354.

RiCKLEFS R.E., LOVETTE I.J. 1999. The roles of island area per se and habitat diversity in the species-area relationships of four Lesser Antillean faunal groups. Journal of Animal Ecology. Vol. 68 p. 1142-1160.

Rolon A.S., Rocha O., MaltchiK L. 2012. Do effects of landscape factors on coastal pond macrophyte communities depend on species traits? Aquatic Botany. Vol. 103 p. $115-121$.

SHANNON C., WeAVER W. 1971. The mathematical theory of communication. Urbana. University of Illinois Press. ISBN 0252725484 pp. 144.

Tabosa A.B., Matias L.Q., Martins F.R. 2012. Live fast and die young: the aquatic macrophyte dynamics in a temporary pool in the Brazilian semiarid region. Aquatic Botany. Vol. 102 p. 71-78.

SMILAUER P., LEPS J. 2014. Multivariate analysis of ecological data using CANOCO $5.2^{\text {nd }}$ ed. Cambridge University Press. ISBN 9781107694408 pp. 373.

Thiere G., Milenkovski S., Lindgren P.E., Sahlen G., Berglund O., WeISNER S.E.B. 2009. Wetland creation in agricultural landscapes: Biodiversity benefits on local and regional scales. Biological Conservation. Vol. 142 p. 964-973. 
Zacharias I., Dimitriou E., DeKKer A., Dorsman E. 2007. Overview of temporary ponds in the Mediterranean region: Threats, management and conservation issues. Journal of Environmental Biology. Vol. 28 p. 1-9.
ZuBALA T. 2005. Możliwość retencjonowania odpływu na przykładzie wybranej zlewni lessowej [Possibility of drainage retention on the example of a loess catchment]. Acta Agrophysica. Vol. 5 p. 219-228.

\section{MONIKA MĘTRAK, Pawel PAWLIKOWSKI, Małgorzata SUSKA-MALAWSKA}

\section{Wiek i sposób użytkowania terenu jako czynniki różnicujące hydrochemię i roślinność zbiorników astatycznych w krajobrazie porolnym}

\section{STRESZCZENIE}

\section{Słowa kluczowe: hydrochemia, roślinność, zbiorniki astatyczne}

Badania prowadzono przez dwa lata na małych zbiornikach wodnych w krajobrazie porolnym w Mazurskim Parku Krajobrazowym. Wybrano 20 zbiorników podzielonych na trzy grupy różniące się wiekiem, stopniem odizolowania i sposobem zagospodarowania otaczających je terenów. Regularnie monitorowano właściwości chemiczne wody w zbiornikach. W celu oszacowania różnic w pokrywie roślinnej zbiorników wykonano zdjęcia fitosocjologiczne metodą Brauna-Blanqueta. Wykazano, że nowopowstałe zbiorniki istotnie statystycznie różnią się od starych poziomem wody, jej odczynem i zawartością jonów wapnia. Najwyższy poziom wody zarejestrowano w starych zbiornikach położonych w otoczeniu półnaturalnych wilgotnych łąk, największą wartość $\mathrm{pH}$ i największe stężenie jonów wapnia - w nowopowstałych zbiornikach. We wszystkich badanych grupach zbiorników poziom wody i wartości badanych parametrów chemicznych podlegały zmienności sezonowej. Roczna dynamika właściwości chemicznych wody nie wykazywała związku z fluktuacjami poziomu wody. Parametry chemiczne wody w starych zbiornikach położonych wśród pól uprawnych nie różniły się od notowanych w starych zbiornikach położonych na obszarze łąk półnaturalnych

$\mathrm{Na}$ nowopowstałych zbiornikach dominowały zbiorowiska charakterystyczne dla otwartej toni wodnej. Brzegi młodych zbiorników charakteryzowały się znacznym udziałem błotnistych, luźno pokrytych roślinnością powierzchni. Różnorodność flory młodych zbiorników, wyrażona liczbą gatunków oraz współczynnikiem Shannona-Weavera, była istotnie mniejsza niż w starych zbiornikach. Zbiorniki stare na półnaturalnych łąkach cechował duży udział gatunków charakterystycznych dla rzędu Molinietalia caeruleae W. Koch 1926 oraz dla związku Magnocaricion Koch 1926. W grupie tych zbiorników zarejestrowano największe wartości wskaźników różnorodności biologicznej.

Na starych zbiornikach otoczonych polami uprawnymi dominowały pałkowiska Typha latifolia. Zaobserwowano także liczne gatunki charakterystyczne dla siedlisk przekształconych przez człowieka (gatunki ruderalne, chwasty). 